marrow. ${ }^{24}$ Possibly in pollinosis seasonal exposure to high concentrations of environmental allergens induces a similar form of $\mathrm{T}$ cell dependent mast cell hyperplasia; and this may contribute in some way to the rapid seasonal deterioration of symptoms.

STEPHEN T Holgate

Reader in medicine and honorary consultant physician

Peter H Howarth Lecturer in medicine

University of Southampton,

Southampton General Hospital,

Southampton SO9 4XY

1 Blackley CH. Experimental researches on the causes and nature of catarrhus aestivus (hay fever or hay asthma). London: Baillière, Tindall and Cox, 1873.

2 Yunginger JW, Gleich GJ. Seasonal changes in serum and nasal IgE concentrations. $\mathcal{F}$ Allengy Clin Immunol 1973;51:174-9.

3 Merrett TG, Hovri M, Mayer ALR, Merrett J. Measurement of specific IgE antibodies in nasal secretions-evidence for local production. Clin Allengy 1976;6:69-73.

4 Ishizaka T, Ishizaka K. Activation of mast cells for mediator release through IgE receptors. In: Ishizaka K, ed. Mast cell activation and mediator release. Pregress in allergy. Vol 34. New York: Karger, 1984.

5 Corrado OJ, Gomez E, Davies TJ. Nasal mast cells: characteristics and effect of allergen. $f$ Allergy Clin Immunol 1985; 75(suppl): 153 .

6 Holgate ST, Robinson C. Mast cell-dependent inflammatory mediators and their putative role in bronchial asthma. Clin Sci 1985;68:103-12.

Mygind N. Mediators of nasal allergy. F Allergy Clin I mmunol 1982;70:149-59.

8 Lewis RA, Austen KF. Mediators of local homeostasis and inflammation by leukotrienes and other mast cell dependent compounds. Nature 1981;293:103-8.

Naclerio RM, Meier HL, Adkinson NF Jr, et al. In vivo demonstration of inflammatory mediator release following nasal challenge with antigen. Eur $\mathcal{F}$ Respir $D$ is 1983;64(suppl 128):26-32.

10 Creticos PS, Peters SP, Adkinson NF, et al. Peptide leukotriene release after antigen challenge in patients sensitive to ragweed. $N$ Engl f Med 1984;310:1626-30.

11 Shaw RJ, Fitzharris P, Cromwell O, Wardlaw AJ, Kay AB. Allergen-induced release of sulphidopeptide leukotrienes (SRS-A) and $\mathrm{LTB}_{4}$ in allergic rhinitis. Allergy 1985;40:1-6.

12 Proud D, Togius A, Naclerio RM, Crush SA, Norman PS, Lichtenstein LM. Kinins are generated in vivo following nasal airway challenge of allergic individuals with allergen. $\mathcal{J} \mathrm{Clin}$ Invest 1983;72:1678-85.

13 Holgate ST, Burns GB, Robinson C, Church MK. Anaphylactic- and calcium-dependent generation of prostaglandin $\mathrm{D}_{2}\left(\mathrm{PGD}_{2}\right)$, thromboxane $\mathrm{B}_{2}$, and other cyclooxygenase products of generation of prostaglandin $\mathrm{D}_{2}\left(\mathrm{PGD}_{2}\right)$, thromboxane $\mathrm{B}_{2}$, and other cyclooxygenase products of 1984;133:2138-44.

14 Norman PS, Naclerio PS, Creticos A, Togias A, Lichtenstein LM. Mediator release after allergic and physical nasal challenges. Proceedings of CIA meeting, Mexico 1984. Int Arch Allergy Appl Immunol (in press).

15 Okuda M, Ohtsuka S, Kawabori S. Basophil leukocytes and mast cells in the nose. Eur $\mathcal{J}$ Respir Dis 1983;64(suppl 128):7-14.

16 Flint KC, Hudspith BN, Leung KBP, Pearce FL, Brostoff J, Johnson McIN. Bronchoalveolar mast cells in extrinsic asthma. Clin Sci 1985;68(suppl):33P.

17 Otsuka H, Denburg J, Dolovich J, et al. Human nasal metachromatic cell (HNMC) heterogeneity: relation to clinical status and response to beclomethasone dipropionate. $f$ Allengy Clin Immunol $1985 ; 75$ (suppl): 153

18 Woodbury RG, Miller HRP. Quantitative analysis of mucosal mast cell protease in the intestine of nippostrongylus-infected rats. Immunology 1982;46:487-95.

19 nippostrongylus-infected rats. I mmunology 1982;46:487-95. Methods Enzymol 1981;80:588-609. 20 Stevens R, Austen KF. Proteoglycans of mast cells. In: Befus D, Bienenstock J, Denbury JA, eds. Mast cell heterogeneity. New York: Academic Press (in press).

Mast cell heterogeneity. New York: Academic Press (in press).
Schwartz LB, Austen KF. Tryptase from human pulmonary mast cells: purification and Schwartz LB, Austen KF. Tryptase from human
characterization. $\mathcal{F}$ Biol Chem 1981;256:11939-43.

22 Metcalf DD, Lewis RA, Silbert JE, Rosenberg RW, Wasserman SI, Austen KF. Isolation and characterization of heparin from human lung. F Clin Invest 1979;64:1537-42.

23 Ihle JN, Keller J, Oroszlan S, et al. Biologic properties of homogeneous interleukin 3. $f$ Immunol 1983;131:282-7.

24 Razin E, Ihle JN, Seldin D, et al. Interleukin 3: a differentiation and growth factor for the mouse mast cell that contains chondroitin sulfate E proteoglycan. F I mmunol 1984;132:1479-86.

\section{Epilepsy and employment}

The idea of possession by demons as the cause of epilepsy disappeared two centuries ago, but sufferers still have to contend with irrational prejudices in society - as well as with justified fears and problems. ${ }^{1}$ In the world of work the combination of real and imaginary barriers may be overwhelming. Recently a conference on epilepsy and employment organised by Labaz - the third it has held on epilepsy -looked at the problems.

Evidence abounds of the difficulties epileptics may have in getting and keeping jobs when their condition is known; between a quarter and three quarters have been found to experience work problems, including having poor jobs. ${ }^{1}$ The conference heard about often unnecessary restrictive and insensitive approaches_even within the NHS. Three separate aspects must be distinguished: the hazards posed by some jobs (to the sufferer or to others) where there is any chance of a seizure at work; where there is no hazard, anxiety and prejudice on the part of employers and fellow workers; and problems other than seizures, such as behavioural and mental abnormalities, that may be associated with the epilepsy or an underlying condition and be the real source of trouble.

The work capacity, including the accident and sickness rates, of those who have epilepsy uncomplicated by other problems is good. ${ }^{1-4}$ The combination of frequent seizures and low social class does, however, make unemployment much more likely. ${ }^{5}$ In a case-control study carried out in the steel industry and reported to the conference by D J Dick, about half of the 45 patients had at least moderate epilepsy and one third had changed their job because of their condition; but in most comparisons of work performance and other features they did not differ significantly from the controls and overall fared adequately in this heavy industry.

As the myth is exploded of the poor work record associated with epilepsy so should prejudice be further dispelled, making concealment less of a temptation to people with epilepsy. As it is, about half are said to conceal their condition (in one study only four of 40 patients had always disclosed $i^{5}$ ), and some doctors apparently do not discourage this. But honesty is the best policy, several speakers emphasised. Concealment may occur even with high risk jobs such as driving; an example quoted was a young bus driver who was discovered to have suffered from epilepsy for 12 years only after killing a motorcyclist during a fit; a medical certificate from someone other than an applicant's own doctor should arouse suspicion. ${ }^{6}$ But in general people fear, often rightly, that their job applications will not be considered on their merits if they admit a history of epilepsy-and moreover that their medical history will not be assessed by anyone knowledgeable. M Espir suggested that employers should follow the Civil Service practice of keeping the medical declaration form separate from the application form, to be looked at only when the candidate's merits have been decided, and that someone should be rejected on medical grounds only after a medical examination.

Behaviour problems cause the most concern in epilepsy, and the element of unpredictability worries employers and fellow workers alike. In addition, there may be cognitive impairment as a result either of disease or of drug treatment. Proposing guidelines on the psychological aspects, E G Lucas emphasised that medical examination of epileptics must cover mental functioning, especially concentration and short term memory. The occupational physician or nurse must also look at stress, so that early intervention and support may be possible-when it is known what circumstances appear to increase seizures. Thus psychological management of epilepsy at the workplace should focus, said Dr Lucas, on making time to understand the individual's total circumstances including those at home; finding out his attitudes; learning about his assets, motivation for work, and relationships with colleagues; and giving advice to the management.

Plenty of practical suggestions came up at the conference for making the best practices more widespread. They centred on removing unnecessary restrictions and providing detailed guidance on the types of work that individuals might do (the National Coal Board's guidelines recommend written instructions to personnel), with careful monitoring and management at the workplace-including initial and continuing 
counselling. Fellow workers as well as employers should be well informed and concerned. A protective code of practice was thought desirable; but the Manpower Services Commission produced a good one on disability in general last year, and that is not well enough known. ${ }^{7}$ It is highly relevant to epilepsy both on recruitment and on promoting the interests of existing employees. In the spirit of this code the basis for placing a person in a job should be, as someone put it, his ability rather than his disability.

Staff Editor,

DAPHNE GLOAG $B M \mathcal{J}$

1 Office of Health Economics. Epilepsy in sociery. London: Office of Health Economics, 1971 2 Rodin EA, Shapiro HL, Lennox K. Epilepsy and life performance. Rehabil Lit 1977;38:34-9. 3 Udel MM. The work performance of epileptics in industry. Arch Environ Health 1960;1:91-8. 4 Kettle M. Disabled people and their employment. Banstead, Surrey: Association of Disabled Professionals, 1979

Scambler G, Hopkins A. Social class, epileptic activity, and disadvantage at work. $\mathcal{I}$ Epidemio Community Health 1980;34:129-33.

6 Raffle PAB. The HGV/PSV driver and loss or impairment of consciousness. In: Godwin-Austen RB, Espir MLE, eds. Driving and epilepsy-and other causes of impaired consciousness. London Royal Society of Medicine, 1982. (International congress and symposium series No 60; proceedings of Labaz symposium.)

7 Manpower Services Commission. Code of good practice on the employment of disabled people. Sheffield: Manpower Services Commission, 1984.

\section{Quinine for night cramps}

Quinine has a long and colourful history. For centuries cinchona bark, from which quinine was first isolated, was used in treating malaria and other feverish illnesses, and quinine remains the drug of choice for chloroquine resistant falciparum malaria. ${ }^{1}$ Because of its bitter taste it is used in tonic water and other drinks, and it is also added to illicit heroin to mask the presence of tasteless adulterants. In the past it also achieved notoriety as an abortifacient. Today the main medical use for quinine in Britain is in treating nocturnal cramp. Little has been published on the complications which occur with regular treatment with quinine at the low doses in which it is used in night cramp. By far the most important problem is the possibility that it might be taken in overdose.

The paper from the Edinburgh regional poisons treatment centre is a salutary reminder of the problems posed by quinine overdose (p 31). The patient may become blind (but will usually recover some vision) and cardiac arrhythmias and deaths may and do occur. A recent report on quinine poisoning from London recorded similar complications, showing that this experience is nation wide. ${ }^{2}$ The management of quinine poisoning is controversial. A large and careful study by Bateman and colleagues throws doubt on claims that the drug is effectively removed by haemodialysis, haemoperfusion, or forced diuresis, and the use of these treatments in quinine overdose does not appear to be justified. ${ }^{3}$ Recovery of vision shortly after the start of these procedures has been reported, ${ }^{4-6}$ but the duration of blindness due to quinine poisoning is often brief, and the recovery might have been coincidental. Certainly it cannot be attributed to the quantity of drug removed.

Stellate ganglion blockade was proposed almost 40 years ago as a treatment for quinine induced blindness and has been widely recommended. ${ }^{7}$ The rationale behind this treatment is to reduce the sympathetic supply to the eye and thus produce vasodilatation. As the Edinburgh team points out, however, the blindness seems to be due to a direct effect on the retina, while arteriolar constriction tends to appear later, often as the blindness is recovering. The procedure is clearly frought with complications, and the evidence for its effectiveness is so meagre there no longer seems to be any indication for its use. Many doctors, however, will not find it easy to stand by and watch their patients going blind. In those moments the natural emotional reaction is to use any treatment which has the remotest possibility of success. The advice must be to stand firm, use commonsense measures aimed at removal of quinine from the gut, give activated charcoal, and provide full supportive treatment.

Because of the potential seriousness of quinine poisoning and the paucity of available remedies prevention is worth every effort. Dyson and colleagues suggest that quinine should not be sugar coated and that it should be dispensed in child resistant containers. This should help prevent accidental quinine poisoning in small children-which may have a sudden tragic outcome owing to fatal cardiac arrhythmias. ${ }^{8}$ Recent evidence that these containers do indeed reduce the incidence of accidental poisoning ${ }^{9}{ }^{10}$ reinforces the argument that quinine should be dispensed in child resistant containers by legislation rather than by the present voluntary agreement. ${ }^{11}$

Night cramps may be regarded as trivial, but this is not the case for the many who suffer from them. They may not be a threat to life, but they are painful, distressing, and disruptive of sleep and composure. We do not know their cause, and unfortunately this condition cannot be studied in animals. They may be provoked by medication, ${ }^{12-14}$ and in this case the remedy is to change the medication rather than falling into the trap of adding quinine to the patient's regimen. They should be distinguished from miner's or stoker's cramp, where sodium loss is the cause and sodium replacement may be curative. ${ }^{14}$ There have been few comparative trials of quinine's effectiveness in relieving night cramps-presumably because it is so clearly successful-and its place seems established until a better treatment is found. ${ }^{15} \mathrm{We}$ do, however, need to understand the nature and causes of night cramps and to find effective remedies which are less toxic than quinine.

JOHN HENRY

Consultant Physician

Poisons Unit,

New Cross Hospital,

London SE14 SER

1 Reynolds JEF, ed. Martindale; the extra pharmacopoeia. 28th ed. London: Pharmaceutical Press, 1982:394-407.

2 Boland ME, Brennand Roper SM, Henry JA. Complications of quinine poisoning. Lancet 1985; 384-5.

3 Bateman DN, Blain PG, Woodhouse KW, et al. Pharmacokinetics and clinical toxicity of quinine overdosage: lack of efficacy of techniques intended to enhance elimination. $Q \mathcal{J} \mathrm{Med}$ 1985;54:125-31.

4 Floyd M, Hill AVL, Ormston BJ, Menzies R, Porter R. Quinine amblyopia treated by haemodialysis. Clin Nephrol 1974;2:44-6.

5 Sabto J, Pierce RM, West RH, Gurr FW. Haemodialysis, peritoneal dialysis, plasmapheresis and forced diuresis for the treatment of quinine overdose. Clin Nephrol 1981;16:264-8.

6 Gibbs JL, Trafford A, Sharpstone P. Quinine amblyopia treated by combined haemodialysis and activated resin haemoperfusion. Lancet 1985; ; 752 -3.

7 Redslob E, Warter J, Isch F. Intoxication par la quinine. Traitement de la surdité et de l'amaurose consécutives par des infiltrations stellaires. Annales d'Oculistique 1946;179:218-20.

8 Garrod GD, Judson JA. Fatal quinine poisoning: a case report. NZ Med f 1981;94:215-6.

9 Clarke $A$, Walton WW. Effects of safety packaging on aspirin ingestion by children. Pediatrics 1979;63:687-93.

10 Jackson RH. Childhood poisoning: perspectives and problems. Hum Toxicol 1983;2:285-93.

11 Craft AW. Circumstances surrounding deaths from accidental poisoning 1974-80. Arch Dis Child 1983;58:544-6.

12 Zelman S. Terbutaline and muscular symptoms. FAMA 1978;230:930

13 Keider S, Binenboim C, Palant A. Muscle cramps during treatment with nifedipine. Br Med $\mathcal{f}$ $1982 ; 285: 1241-2$

14 Joekes AM. Cramp: a review. $\mathcal{I} R$ Soc Med 1982;75:546-9.

15 British Medical Association and Pharmaceutical Society of Great Britain. British nátional formulary. No 9. London: British Medical Association, 1985:324. 